\title{
Effect of Quantitative Early Feed Restriction on Growth Performances, Meat Quality, Abdominal Fat and Serum Lipid Profile in Broiler Chicken
}

\author{
H.P.B.S. Jayasiri, W.A.D. Nayananjalie* and A.M.J.B. Adikari \\ Department of Animal and Food Sciences, Faculty of Agriculture, Rajarata University of Sri \\ Lanka \\ *nayananjalie@yahoo.com
}

\begin{abstract}
Excessive fat in modern broiler strains is one of the major problems faced by the broiler industry. This experiment was conducted to study the effect of feed restriction at early age on broiler chicken performance, meat quality, abdominal fat content, and serum lipid profile. Two hundred, Cobb500 day-old broiler chicks were randomly assigned into five treatments; T1: ad-libitum feeding (control), T2 and T3: 75 and $50 \%$ of ad-libitum feeding from day 8 - 14, respectively, T4 and T5: 75 and 50\% of ad-libitum feeding from day $15-21$, respectively. All birds were fed with ad-libitum before and after the completion of the respective restriction periods. Total feed intake was significantly lower $(\mathrm{p}<0.05)$ in T3 and T5 compared to the birds in the control group. However, no differences $(p>0.05)$ were observed in weight gain, feed conversion ratio, and dressing percentage among the treatments. Abdominal fat and muscle crude fat contents in birds fed with restricted diets from day 8 - 14 were significantly lower $(\mathrm{p}<0.05)$ compared to the control. There was no influence $(\mathrm{p}>0.05)$ of treatments on organ weights, muscle protein contents, and serum lipid profile. In conclusion, $50 \%$ feed restriction during day 8 - 14 is a better solution to reduce the fat deposition without interfering on growth performances of broiler chicken with lower cost.
\end{abstract}

Key words: Abdominal fat, Carcass quality, Feeding, Lipid, Profit

\section{Introduction}

In past, the main goal of the broiler producers was to increase the growth rate of broiler chickens for obtaining economic benefits within a short time [Peng et al., 2016]. As a result, modern broiler strains show a fast growth rate. Unfortunately, the increase of growth rate is associated with high body fat deposition and mortality, incidences of skeletal disorders and metabolic diseases which directly lead to remarkable economic losses [Tumov \& Teimouri, 2010]. The excessive amount of non-carcass fat deposition at the market age of bird is a common problem faced by the broiler farmers. The excessive fat reduces the carcass yield and consumer acceptance. It is also considered as a waste product that consumes the dietary energy [Shahin \& El Azeem, 2006].

Meat, especially the red meat is classified as a food with high contents of cholesterol, fat, saturated fatty acids and low levels of unsaturated fatty acids [Shahin \& El Azeem, 2006]. Normally, poultry meat contains a lower amount of saturated fatty acids and a higher amount of polyunsaturated fatty acids than the lean meat of mammals
[Cristina, 2009]. However, present strains of broilers contain 15 - $20 \%$ body fat, of which more than $85 \%$ is not physiologically required for body functions [Choct et al., 2005]. Fats in the ready-to-cook bird cause to appear a fatty image to poultry meat. Intake of saturated fat in the human diet has been reported to increase blood cholesterol level and the incidence of coronary heart diseases, atherosclerosis, and cancer [Popova et al., 2016]. Therefore, excessive fat deposition is an unfavorable trait from the view of both meat producers and consumers. Not only urban areas but also in rural households, consumers try to find low-fat, low-calorie, highprotein, cheap broiler meat [Prabakaran, 2003].

Because of economic concerns and consumer objections to excess fat deposition, feeding strategies to reduce the body fat content in the broiler carcass is an important topic for the research. Previous studies showed that broiler chickens have a fast growth rate during their early ages which is one of the main reasons for excessive body fat deposition. This situation is the most critical in broiler chickens that are reared with ad-libitum feeding, due to increase feed intake [Tumov \& Teimouri, 2010]. However, feed re- 
Table 1: Feeding schedule of treatments

\begin{tabular}{lcc}
\hline Treatments & Day 8 -14 & Day $15-21$ \\
\hline T1(Control) & ad-libitum feeding & ad-libitum feeding \\
T2 & 75\% of ad-libitum feeding & ad-libitum feeding \\
T3 & 50\% of ad-libitum feeding & ad-libitum feeding \\
T4 & ad-libitum feeding & $75 \%$ of ad-libitum feeding \\
T5 & ad-libitum feeding & $50 \%$ of ad-libitum feeding \\
\hline
\end{tabular}

The amount of feed which should be fed to birds in T2, T3, T4, and T5 was calculated based on the previous day feed intake of birds in control (T1) treatment.

striction regimes have some success in increasing leanness in broilers [Choct et al., 2005]. Nutritional studies have indicated that the various processes involved in adiposity can be altered by the level of feeding especially at an early age [Tumov \& Teimouri, 2010]. Therefore, this study was conducted to evaluate the early quantitative feed restriction on the growth performance, meat quality, abdominal fat and serum lipid profile in the broiler chickens.

\section{Methods}

\section{Experiment Location}

Field work and laboratory analysis were conducted at Livestock farm and Animal and Food Science laboratory in Faculty of Agriculture, Rajarata University of Sri Lanka, Puliyankulama, Anuradhapura, from $5^{\text {th }}$ February to $15^{\text {th }}$ August 2018 respectively.

\section{Broiler Management Practices}

In the week prior to arrival of chicks, poultry house was cleaned. Brooder guards, feeders and waterers were thoroughly cleaned in the previous day and a foot bath was prepared. Day old broiler chicks were purchased from a commercial hatchery and transported to the experimental location. After arrival, they were weighed and provided glucose solution (Vitaguard) with drinking water to protect them from stress. Then, they were randomly introduced into two brooders of one hundred chicks per each and reared under good hygienic conditions. During this period, chicks had free access to water and feed. Electric bulbs (100 W) were used as the initial heating and lighting source for 24 hours of the day. Paddy husk was used as the litter material. Chicks were spent seven days of brooding period. All chicks were provided with multi-vitamins (Bio-Vitamino Oral and Selvite-E) and Antibiotic (Enrocip) to avoid the risk of diseases during brooding. All birds were vaccinated against infectious bursal disease (IBD) at age of 7 and 14 days.

\section{Birds and Experimental Design}

A total of two hundred, Cobb 500 broiler chicks were used in the experiment. After 7 days of brooding period, they were randomly assigned to five treatments (Table 1) with four replicates per each treatment. Ten chicks were included in a replicate.

Broiler starter ration was fed from day 1 to day 21 and after 21 days of feeding, starter ration was gradually changed into the finisher which was continued until slaughtering. Nutritional composition of commercial feeds is presented in Table 2. During day 22 - 38, they were fed ad-libitum. Water was provided with ad-libitum and all other general management practices were followed until birds were slaughtered.

\section{Slaughtering of Broilers}

Three birds were randomly selected from each replicate at the $38^{\text {th }}$ day of age for slaughtering and they were fasted for 12 hours. Ante-mortem assessments were done by visual observations and body weights of birds were recorded. Birds were held in killing cones and major blood vessels (carotid arteries and jugular veins) were cut within 10 seconds and kept for bleeding at least for 2 minutes. Slaughtered birds were scalded in hot water at the temperature of $56{ }^{\circ} \mathrm{C}$ for $2-5$ minutes. The defeathering machine was used to remove the feathers and remained feathers were shaved. Then, a cut was made at the end of the abdomen and abdominal cavity was opened and the digestive tract, 
Table 2: Nutritional composition of the commercial feeds

\begin{tabular}{lcc}
\hline Nutrients & Starter & Finisher \\
\hline Protein (\%) & 22 & 20 \\
Fat (\%) & 6 & 7 \\
Ash (\%) & 7 & 7.5 \\
Fiber (\%) & 4.5 & 4.5 \\
Calcium (\%) & $9.5-1.2$ & $0.9-1.2$ \\
Phosphorous (\%) & $0.7-1$ & $0.7-1$ \\
Metabolizable Energy (kcal / kg) & 3000 & 3100 \\
\hline
\end{tabular}

respiratory tract, and heart were removed. After proper cleaning, liver, heart, and gizzard were collected as giblets.

\section{Data Collection and Calculations}

Given feed quantity and remaining quantity were measured daily and then feed intake was calculated throughout the experimental period. Body weight was measured weekly, per pen basis and weight gain was calculated. Feed conversion ratio (FCR) was also calculated. Live weight at slaughtering and carcass weights were recorded and dressing percentage was calculated. The weights of body parts (breast, legs, and wings) were taken and expressed as a percentage of the carcass weight. Giblet weights (heart, liver, gizzard, and neck) were also recorded. Weights of abdominal fat pads were also measured.

The feed costs of starter and finisher rations throughout the study period were recorded. Feed cost per kg of live weight and feed cost per salable carcass were calculated.

\section{Sample Collection and Analysis}

After slaughtering, meat samples were taken from the breast area of birds and dry matter, crude fat, crude protein, total ash, crude fiber contents were determined [AOAC, 2003].

Blood samples were properly collected to sterilize tubes (without anticoagulant) at slaughtering from three randomly selected birds representing each replicate. Serum was immediately separated by centrifugation at $1500 \mathrm{rpm}$ for $20 \mathrm{~min}$ (Labnet Int-C406490, USA). Then, samples were stored in $-20{ }^{\circ} \mathrm{C}$ until further analysis. The serum samples were tested for total cholesterol, high den- sity lipoproteins (HDL), triglycerides (TAG) and low density lipoproteins (LDL) using a commercial kit (BIOLABO, France) as per the manufacturers guidelines using a spectrophotometer (LABOMED, USA).

\section{Data Analysis}

Experiment was conducted in a completely randomized design (CRD). Statistical analyses were done using one-way Analysis of Variance (ANOVA) procedure in Statistical Analysis Software, version 9.0 [SAS, 2002]. Mean separation was done by Turkey's Standardized Range Test (TSRT). Statistical significance was declared at $\mathrm{p}<0.05$.

\section{Results and Discussion}

\section{Growth Performances}

Effect of each treatment on feed intake, weight gain and feed conversion ratio (FCR) during the experimental period are presented in Table 3 . There were significant differences $(\mathrm{p}<0.05)$ in feed intake among different treatments during day $8-21$. The lowest feed intake was reported in the birds fed with $50 \%$ restricted diet during day $8-14$ and day $15-21$. The significantly $(\mathrm{p}<0.05)$ highest intake was observed in the birds allotted in control treatment compared to the other treatments. Mahmood et al. (2007) reported similar results and birds reared under restricted feeding in second, and third weeks of age consumed lower amount of feed compared to the ad-libitum feeding. Novele et al. (2009) observed lower feed intake in 50\% feed restricted birds compared to $25 \%$ restricted and adlibitum fed birds at age of 21 days.

However, there were no any differences $(\mathrm{p}>0.05)$ in feed intake among the treatments during the fin- 
Table 3: Feed intake, body weight gains and feed conversion ratio of broilers fed with different feed restriction regime

\begin{tabular}{|c|c|c|c|c|c|c|c|}
\hline \multirow{3}{*}{ Parameter } & \multicolumn{5}{|c|}{ Treatments* } & \multirow{3}{*}{$\mathbf{P}$ value } & \multirow{3}{*}{ SE } \\
\hline & \multirow{2}{*}{ Control } & \multicolumn{2}{|c|}{ Day 8-14 } & \multicolumn{2}{|c|}{ Day 15-21 } & & \\
\hline & & $75 \%$ & $50 \%$ & $75 \%$ & $50 \%$ & & \\
\hline \multicolumn{8}{|c|}{ Feed intake $(\mathrm{g})$} \\
\hline Day 8-14 & $361^{\mathrm{a}}$ & $248^{\mathrm{b}}$ & $184^{\mathrm{c}}$ & $356^{\mathrm{a}}$ & $315^{\mathrm{d}}$ & 0.0001 & 6 \\
\hline Day 15-21 & $624^{\mathrm{a}}$ & $613^{\mathrm{a}}$ & $595^{\mathrm{a}}$ & $442^{\mathrm{b}}$ & $294^{\mathrm{c}}$ & 0.0001 & 10 \\
\hline Day 8-21 & $985^{\mathrm{a}}$ & $861^{\mathrm{b}}$ & $779^{\mathrm{c}}$ & $798^{\mathrm{c}}$ & $609^{\mathrm{d}}$ & 0.0001 & 12 \\
\hline Day 22-38 & 2087 & 2092 & 2069 & 2145 & 2142 & 0.358 & 32 \\
\hline Day 8-38 & $3072^{\mathrm{a}}$ & $2953^{\mathrm{ab}}$ & $2849 b^{c}$ & $2944^{\mathrm{ab}}$ & $2752^{\mathrm{c}}$ & 0.0008 & 41 \\
\hline \multicolumn{8}{|c|}{ Body weight gain (g) } \\
\hline Day 8-14 & $258^{\mathrm{a}}$ & $193^{\mathrm{b}}$ & $137^{\mathrm{c}}$ & $268^{\mathrm{a}}$ & $260^{\mathrm{a}}$ & 0.1931 & 12 \\
\hline Day $15-21$ & $521^{\mathrm{a}}$ & $457^{\mathrm{ab}}$ & $416^{\mathrm{bc}}$ & $327^{\mathrm{cd}}$ & $239^{\mathrm{d}}$ & 0.0001 & 22 \\
\hline Day 8-21 & $779^{\mathrm{a}}$ & $650^{\mathrm{b}}$ & $553^{\mathrm{dc}}$ & $595^{\mathrm{bc}}$ & $499^{\mathrm{d}}$ & 0.0001 & 22 \\
\hline Day $22-38$ & $1230^{\mathrm{b}}$ & $1325^{\mathrm{ab}}$ & $1429^{\mathrm{a}}$ & $1433^{\mathrm{a}}$ & $1469^{\mathrm{a}}$ & 0.0045 & 40 \\
\hline Day 8-38 & 2009 & 1974 & 1982 & 2029 & 1968 & 0.8226 & 42 \\
\hline \multicolumn{8}{|l|}{ FCR } \\
\hline Day 8-14 & 1.42 & 1.29 & 1.38 & 1.34 & 1.21 & 0.5366 & 0.09 \\
\hline Day $15-21$ & 1.2 & 1.35 & 1.43 & 1.36 & 1.3 & 0.4359 & 0.08 \\
\hline Day 8-21 & 1.27 & 1.33 & 1.41 & 1.35 & 1.23 & 0.1931 & 0.05 \\
\hline Day $22-38$ & $1.70^{\mathrm{a}}$ & $1.58^{\mathrm{ab}}$ & $1.46^{\mathrm{b}}$ & $1.50^{\mathrm{ab}}$ & $1.46^{\mathrm{b}}$ & 0.0184 & 0.05 \\
\hline Day 8-38 & 1.53 & 1.5 & 1.44 & 1.45 & 1.4 & 0.1867 & 0.04 \\
\hline
\end{tabular}

$\mathrm{a}, \mathrm{b}, \mathrm{c}, \mathrm{d}$ means within the same row with different superscripts are significantly different $(\mathrm{p}<0.05)$.

${ }^{*}$ Control= ad-libitum feeding, $75 \%$ @ day $8-14=$ Provide $75 \%$ of ad-libitum feeding from day 8 - 14 of age, $50 \%$ @ day 8

- $14=$ Provide $50 \%$ of ad-libitum feeding from day $8-14$ of age, $75 \%$ @ day $15-21=$ Provide $75 \%$ of ad-libitum feeding from day $15-21$ of age, $50 \%$ @ day $15-21=$ Provide $50 \%$ of ad-libitum feeding from day $15-21$ of age.

isher period (day $22-38$ ). Further, when total feed intake (from day 8 - 38) was considered, feed intakes were similar among ad-libitum feeding group and $25 \%$ feed restricted birds. However, the feed intake of $50 \%$ feed restricted groups were significantly lower $(\mathrm{p}<0.05)$ compared to the ad-libitum fed group. These findings were in agreement with Plavnik \& Hurwitz (1988) who reported reduced feed intakes with feed restriction without considering the age.

As the result indicated in table 3 , the significantly highest $(\mathrm{p}<0.05)$ body weight gain was ob- served in the control group compared to the other treatments during day 8 - 21. Santoso (2001) observed similar results in body weight gain of birds fed ad-libitum as compared to the restricted feeding birds at the end of restriction period of 3 - 9 days. However, during the finisher period, birds allotted in control treatment showed the lowest $(\mathrm{p}<0.05)$ weight gain while the highest gain was observed in $50 \%$ feed restricted group and the birds fed with $25 \%$ restricted diet in the $3^{\text {rd }}$ week. However, when considered the total experimental period, there were no any differences $(\mathrm{p}>0.05)$ in weight gain 
Table 4: Live weight, carcass weight, dressing percentage, carcass cuts and organ weights of broilers fed in different feed restriction regimes

\begin{tabular}{|c|c|c|c|c|c|c|c|}
\hline \multirow{3}{*}{ Parameter } & \multicolumn{5}{|c|}{ Treatments* } & \multirow{3}{*}{$\mathbf{P}$ value } & \multirow{3}{*}{$\mathrm{SE}$} \\
\hline & \multirow{2}{*}{ Control } & \multicolumn{2}{|c|}{ Day 8-14 } & \multicolumn{2}{|c|}{ Day 15-21 } & & \\
\hline & & $75 \%$ & $50 \%$ & $75 \%$ & $50 \%$ & & \\
\hline Live weight, $\mathrm{kg}$ & 2.17 & 2.13 & 2.12 & 2.19 & 2.1 & 0.7424 & 0.05 \\
\hline Carcass weight, $\mathrm{kg}$ & 1.63 & 1.67 & 1.62 & 1.7 & 1.61 & 0.6846 & 0.05 \\
\hline Dressing \% & 75.45 & 78.14 & 76.23 & 77.52 & 76.45 & 0.3995 & 1 \\
\hline Abdominal fat (\% carcass weight) & $1.7^{\mathrm{a}}$ & $1.0^{\mathrm{b}}$ & $0.8^{\mathrm{b}}$ & $1.3^{\mathrm{ab}}$ & $1.6^{\mathrm{a}}$ & 0.0007 & 0.10 \\
\hline \multicolumn{8}{|l|}{ Carcass cuts (\% carcass weight) } \\
\hline Breast & 36 & 31.6 & 34.7 & 35.4 & 32.4 & 0.6134 & 2.3 \\
\hline Leg & 27.9 & 28.9 & 27.4 & 26.4 & 27 & 0.8493 & 1.6 \\
\hline Wings & 11.9 & 11.1 & 10.5 & 9.6 & 11.4 & 0.0566 & 0.5 \\
\hline \multicolumn{8}{|c|}{ Internal organs (\% carcass weight) } \\
\hline Liver & 2.4 & 2.4 & 2.5 & 2.2 & 2.2 & 0.4904 & 0.16 \\
\hline Heart & 0.48 & 0.51 & 0.59 & 0.52 & 0.57 & 0.4175 & 0.05 \\
\hline Gizzard & 1.37 & 1.86 & 1.39 & $1 . .43$ & 1.75 & 0.0891 & 0.15 \\
\hline Neck & 2.5 & 2.8 & 2.9 & 3 & 2.9 & 0.3881 & 0.19 \\
\hline
\end{tabular}

${ }^{a},{ }^{b}$ means within the same row with different superscripts are significantly different $(\mathrm{p}<0.05)$.

${ }^{*}$ Control = ad-libitum feeding, 75\% @ day 8 - $14=$ Provide 75\% of ad-libitum feeding from day 8 - 14 of age, $50 \%$ @ day $8-14=$ Provide $50 \%$ of ad-libitum feeding from day $8-14$ of age, $75 \%$ @ day $15-21=$ Provide $75 \%$ of ad-libitum feeding from day 15 - 21 of age, $50 \%$ @ day 15 - 21 = Provide $50 \%$ of ad-libitum feeding from day 15 - 21 of age.

among the treatments. The probable explanation for this consequence in the present study that, the compensatory growth might have occurred when restricted birds were re-fed ad-libitum after early restriction period. These results were in agreement with the previous findings of Santoso (2001), Santoso et al. (1995), Novele et al. (2009) and Plavnik \& Hurwitz (1988, 1989). Dozier et al. (2002) also reported similar findings and the feed-restricted broilers gained greater body weight than ad-libitum feeding during their re-alimentation period.

During the day $8-21$, FCR of birds in different treatments was not significantly different $(\mathrm{p}>0.05)$ (Table 3). Previous studies also reported similar findings in the starter period [Mohebodini et al., 2009]. However, birds in the control group reported the highest $(\mathrm{p}<0.05)$ FCR in the finisher period and it did not differ from birds allotted in $25 \%$ feed restricted groups. The significantly lower $(\mathrm{p}<0.05)$ FCR values were observed in the $50 \%$ feed restricted groups compared to the ad-libitum fed group during the finisher period. However, when considered the total study period, FCR values did not differ $(\mathrm{p}>0.05)$ among the birds in different treatments. It proved that the feed-restricted broilers attained improvement in feed conversion after the feed restriction and that was in agreement with the findings of Deaton (1995), Plavnik \& Hurwitz (1988) and Zubair \& Lesson (1996). The study of Yu et al. (1990) reported feed efficiency reduced for the restricted chicks in the first week after resuming ad-libitum feeding, but later it was slightly improved beyond the feed efficiency for the unrestricted chicks. However, the effect of feed restriction has yielded inconsistence findings in the literature. For example, Santoso (2001) reported the level or duration of feed restriction had no effect on FCR. On the other hand, Mahmood et al. (2007) reported that the 
Table 5: Meat composition of broiler chickens fed in different feed restriction regime

\begin{tabular}{|c|c|c|c|c|c|c|c|}
\hline \multirow{3}{*}{ Nutrients } & \multicolumn{5}{|c|}{ Treatments* } & \multirow{3}{*}{$P$ value } & \multirow{3}{*}{$\mathrm{SE}$} \\
\hline & \multirow{2}{*}{ Control } & \multicolumn{2}{|c|}{ Day 8-14 } & \multicolumn{2}{|c|}{ Day 15-21 } & & \\
\hline & & $75 \%$ & $50 \%$ & $75 \%$ & $50 \%$ & & \\
\hline Dry matter & 36.55 & 39.2 & 34.73 & 33.18 & 35.41 & 0.7826 & 3 \\
\hline Ash & 1.22 & 1.45 & 1.41 & 1.36 & 1.3 & 0.9572 & 0.22 \\
\hline Protein & 9.69 & 10 & 9.56 & 9.65 & 9.4 & 0.3138 & 0.19 \\
\hline Fat & $5.06^{\mathrm{a}}$ & $2.52^{\mathrm{b}}$ & $1.88^{\mathrm{b}}$ & $5.81^{\mathrm{a}}$ & $3.43^{\mathrm{ab}}$ & 0.0009 & 0.57 \\
\hline Fiber & 2.01 & 1.94 & 2.18 & 1.66 & 1.75 & 0.5838 & 0.24 \\
\hline
\end{tabular}

$\mathrm{a}, \mathrm{b}$ means within the same raw with different superscripts are significantly different $(\mathrm{p}<0.05)$.

${ }^{*}$ Control = ad-libitum feeding, 75\% @ day 8 - $14=$ Provide $75 \%$ of ad-libitum feeding from day 8 - 14 of age, $50 \%$ @ day $8-14=$ Provide $50 \%$ of ad-libitum feeding from day $8-14$ of age, $75 \%$ @ day $15-21=$ Provide $75 \%$ of ad-libitum feeding from day 15 - 21 of age, $50 \%$ @ day $15-21=$ Provide $50 \%$ of ad-libitum feeding from day $15-21$ of age.

birds reared under different feed restriction regimes utilized their feed more efficiently than those who fed with ad-libitum. Variations in results may be attributable to differences in feeding regimens practiced in different studies.

\section{Carcass Characteristics of Broilers}

According to Table 4, the differences were not significant $(\mathrm{p}>0.05)$ for live weight, carcass weight and dressing percentage at $38^{\text {th }}$ day of age among the treatments. Therefore, these findings indicated that complete compensation occurs in broilers during their re-feeding period after feed restriction. Lee \& Lesson (2001) suggested that there are no losses of meat yield if birds are able to attain compensatory growth during their re-alimentation pe- riod after feed restriction.

However, there was a significant difference $(\mathrm{p}<0.05)$ in abdominal fat weight among the treatments. The back fat weight was significantly $(\mathrm{p}<0.05)$ higher in birds fed ad-libitum compared to the feed-restricted group at their $2^{\text {nd }}$ week of age. However, fat contents were similar in the $a d$ libitum fed birds and birds fed restricted feeds at their $3^{\text {rd }}$ week of age. Hence, feed restriction at the day 8 - 14 age influenced the abdominal fat deposition in broilers. Santoso (2001) reported the similar findings and they observed a significant reduction in abdominal fat percentage and accumulation of fat in the body at the market weight when birds fed with $25 \%$ of ad-libitum for 9 days starting on

Table 6: Serum lipid profile of broilers fed in different feed restriction regime

\begin{tabular}{lccccccc}
\hline \multirow{2}{*}{$\begin{array}{l}\text { Parameter** } \\
(\mathbf{m g} / \mathbf{d L})\end{array}$} & Control & \multicolumn{9}{c}{ Day } & $\mathbf{8 - 1 4}$ & \multicolumn{1}{c}{ Day } & $\mathbf{1 5 - 2 1}$ & & P value & SE \\
\cline { 2 - 6 } & & $\mathbf{7 5 \%}$ & $\mathbf{5 0 \%}$ & $\mathbf{7 5 \%}$ & $\mathbf{5 0 \%}$ & & \\
\hline TCH & 181 & 184 & 177 & 173 & 179 & 0.9831 & 14 \\
TAG & 73 & 64 & 70 & 83 & 75 & 0.5196 & 8 \\
HDL & 35 & 39 & 30 & 31 & 35 & 0.4017 & 3 \\
LDL & 146 & 145 & 146 & 143 & 145 & 0.9997 & 15 \\
\hline
\end{tabular}

Control = ad-libitum feeding, $75 \%$ @ day 8 - $14=$ Provide $75 \%$ of ad-libitum feeding from day 8 - 14 of age, $50 \%$ day 8 - $14=$ Provide $50 \%$ of ad-libitum feeding from day $8-14$ of age, $75 \%$ @ day $15-21=$ Provide $75 \%$ of ad-libitum feeding from day $15-21$ of age, $50 \%$ @ day $15-21=$ Provide $50 \%$ of ad-libitum feeding from day $15-21$ of age.

${ }^{*}$ TCH $=$ Total cholesterol, TAG $=$ Triglycerides, HDL $=$ High density lipoprotein, LDL = Low density lipoprotein. 
Table 7: Feed cost analysis on the basis of live and salable weight

\begin{tabular}{lccccccc}
\hline & \multicolumn{9}{c}{ Treatments* } & & \\
\cline { 2 - 6 } Cost (LKR) & Control & Day & $\mathbf{8 - 1 4}$ & Day & $\mathbf{1 5 - 2 1}$ & \multirow{2}{*}{ P value } & SE \\
\cline { 2 - 6 } & & $\mathbf{7 5 \%}$ & $\mathbf{5 0 \%}$ & $\mathbf{7 5 \%}$ & $\mathbf{5 0 \%}$ & & \\
\hline Feed cost/ 1 kg of live weight & 142.00 & 139.00 & 136.00 & 135.00 & 131.00 & 0.4284 & 4.0 \\
Feed cost/ 1 kg of salable weight & 189.00 & 178.00 & 178.00 & 175.00 & 172.00 & 0.3655 & 6.0 \\
\hline
\end{tabular}

Control = ad-libitum feeding, $75 \%$ @ day 8 - 14 = Provide $75 \%$ of ad-libitum feeding from day 8 - 14 of age, $50 \%$ day 8 - $14=$ Provide $50 \%$ of ad-libitum feeding from day $8-14$ of age, $75 \%$ @ day $15-21=$ Provide $75 \%$ of ad-libitum feeding from day 15 - 21 of age, $50 \%$ @ day $15-21=$ Provide $50 \%$ of ad-libitum feeding from day $15-21$ of age.

the first day of the $2^{\text {nd }}$ week of age. Further, Santoso et al. (1993) suggested that quantitative feed restriction reduced the fat deposition by inhibiting the activity of the rate-limiting enzyme during lipogenesis in the liver of chickens. These findings are also in agreement with the findings of Yang et al. (2010).

There were no any significant differences ( $\mathrm{p}>0.05)$ among treatments in breast, leg, wings, liver, heart, gizzard and neck weights as a percentage of carcass weight. Mahmood et al. (2007), Mahmood et al. (2005) and Azahan (1984) also reported similar relative weights of heart, liver, spleen, gizzard, pancreas, and intestine in feed restricted and ad-libitum fed birds. Further, these findings were in accordance with the findings reported by Mahmood et al. (2007), Mahmood et al. (2005) and Azahan (1984). Moreover, Novele et al. (2009) determined the effect of different feed restriction regimes during the 15 - 21 days of age and reported that, the level of feed restriction and the sex of the chicken had no effect on breast, thigh, drumstick, wing, gizzard and liver weights when expressed as percentage of carcass weight at 42 days of age.

\section{Meat Quality Parameters}

According to the proximate composition, there was no any significant $(\mathrm{p}>0.05)$ difference in dry matter, ash, protein and fiber contents of meat samples among the treatments. However, muscle fat content was significantly higher $(\mathrm{p}<0.05)$ in birds fed ad-libitum compared to the birds which fed restricted diet in their $2^{\text {nd }}$ week of age. However, the muscle fat contents were similar among the birds in control treatment and feed restricted groups in the $3^{\text {rd }}$ week of age. Therefore, feed restriction in $8-14$ days of age had the significant effect on fat composition in chicken. Santoso (2001) showed that there was no effect in feed restriction on moisture and protein contents in chickens, but fat contents greatly reduced in feed restricted broilers compared to full fed broilers. Further, Zhan et al. (2007) and Omosebi et al. (2014) reported that fat content was lower whereas crude protein content was higher in feed restricted chickens than ad-libitum fed chicken. Moreover, Giachetto et al. (2003) indicated that there is no restriction effect on broiler carcass protein and total fat content. These discrepancies observed in literature may be due to the variation in feeding regime as well as the different levels and duration of feed restriction within the experiment.

\section{Blood Serum Parameters}

As per the table 6, there were no any significant differences $(\mathrm{p}>0.05)$ in total cholesterol, triglyceride, high-density lipoprotein (HDL) and low-density lipoprotein (LDL) levels in serum of birds in different treatments. At slaughtering, similar feed intake and growth performances were observed in each treatment. Therefore, it can be assumed that their metabolic processes were closely related to each other. Similar findings were observed by Alaquil \& Zulkifli (2009) and showed that the effects of feeding regime on serum levels of cholesterol, glucose, potassium, and chloride were not different in broilers. On the other hand, Dawood (2015) reported that, the total plasma lipids, triacylglycerol, cholesterol, HDL were lower in the feed-restricted chickens, especially during the later phase of the experiment. Santoso (2001) also stated that serum triglycerides were significantly lower whereas cholesterol content was not significantly different in chicks reared in ad-libitum compared to restrict feeding. Mohebodini et al. (2009) and 
Zhan et al. (2007) reported that serum triglyceride concentration has reduced in broilers at the end of the experiment.

\section{Feed Cost Analysis}

As per the table 7 , there was no any significant difference $(p>0.05)$ among the treatments on the cost spent for feeds to produce $1 \mathrm{~kg}$ of live weight and salable weight. However, the highest and lowest feed cost to produce $1 \mathrm{~kg}$ of live weight and salable weight were observed in birds fed with $a d$ libitum and $50 \%$ feed restriction in the $3^{\text {rd }}$ week of age, respectively.

\section{Conclusions}

Fifty percent feed restriction during day 8 - 14 reduces the feed intake of birds without affecting the weight gain, feed conversion ratio or dressing percentage compared to the birds fed ad-libitum. Further, abdominal and muscle crude fat contents in birds fed with restricted diets from day 8 - 14 reduce compared to the ad-libitum fed birds. A lower feed cost to produce $1 \mathrm{~kg}$ of live and salable weight is also observed in birds fed with $50 \%$ feed restriction in the $2^{\text {nd }}$ week of age compared to the birds fed with ad-libitum. Hence, $50 \%$ feed restriction during day 8 - 14 reduces the fat deposition without interfering on growth performances in broiler chicken with lower cost.

\section{References}

Alaquil, A. \& Zulkifli, I. (2009). Changes in heat shock protein 70 expression and blood characteristics in transported broiler chickens as affected by housing and early age feed restriction, Poultry Science, v. 88(2): pp. 1358-1364, DOI: 10.3382/ps.2008-00554.

AOAC (2003). Official methods of analysis. Association of official analytical chemists (18th ed.). Washington DC, USA.

Azahan, E.N.G.K.U. (1984). Response of broilers to a restriction in feeding time. MARDI Research Bulletin, v. 12(3): pp. 361-365.

Choct, M., Naylor, A.J. \& Oddy, V.H. (2005). Dietary manipulation of lean tissue deposition in broiler chickens, Asian-Australasian Journal of Animal Sciences, v. 18(5): pp. 692-698, DOI: 10.5713/ajas.2005.692.
Cristina, B. (2009). Quality of poultry meat and factors that define it. Faculty of Environmental Protection, University of Oradea, Oradea, Romania.

Dawood, H. (2015). The effect of feed restriction on broiler performance, and serum carcass lipids: A Review. Department of Animal Production, Faculty of Agriculture, Western Darfour, University of Zalingei, Sudan.

Deaton, J.W. (1995). The effect of early feed restriction on broiler performance. Poultry Science, v. 74 (8): pp. 1280-1286, DOI: $10.3382 /$ ps.0741280

Dozier, W.A., Lien, R.J., Hess, J.B., Bilgili, S.E., Gordon, R.W., Laster, C.P. \& Vieira, S.L. (2002). Effects of early skip-a-day feed removal on broiler live performance and carcass yield. Journal of Applied Poultry Research, v. 11(3): pp. 297-303, DOI: $10.1093 /$ japr/11.3.297

Giachetto, P.F., Guerreiro, E.N., Ferro, J.A., Ferro, M.I.T., Furlan, R.L. \& Macari, M. (2003). Performance and hormonal profile of broilers fed different energy levels after food restriction. Brazilian Agricultural Research, v. $38(6)$ : pp. $697-702$, DOI: $10.1590 / \mathrm{s} 0100-$ $204 \times 2003000600005$.

Lee, K.H. \& Leeson, S. (2001). Performance of broilers fed limited quantities of feed or nutrients during seven to fourteen days of age. Poultry Science, v. 80(4): pp. 446-454, DOI: 10.1093/ps/80.4.446.

Mahmood, S., Hassan, S., Ahmed, F., Ashraf, M., Alam, M. and Muzaffar, A. (2005). Influence of feed withdrawal for different durations on performance of broilers in summer. International Journal of Agriculture and Biology, v. 7(6): pp. 975-978.

Mahmood, S., Mehmood, S., Ahmad, F., Masood, A. \& Kausar, R. (2007). Effects of feed restriction during starter phase on subsequent growth performance, dressing percentage, relative organ weights and immune response of broilers. Pakistan Veterinary Journal, v. 27(3): pp. 137141.

Mohebodini, H., Dastar, B., Sharg, M.S. \& Zerehdaran, S. (2009). The comparison of early feed restriction and meal feeding on performance, 
carcass characteristics and blood constituents of broiler chickens. Journal of Animal and Veterinary Advances, v. 8(10): pp. 2069-2074.

Novele, D.J., Ng'ambi, J.W., Norris, D. \& Mbajiorgu, C.A. (2009). Effect of different feed restriction regimes during the starter stage on productivity and carcass characteristics of male and female Ross 308 broiler chicken. International Journal of Poultry Science, v. 8(1): pp. 35-39, DOI: 10.3923/ijps.2009.35.39.

Omosebi, D.J., Adeyemi, O.A., Sogunle, O.M., Idowu, O.M.O. \& Njoku, C.P. (2014). Effects of duration and level of feed restriction on performance and meat quality of broilerchickens. Archivos de zootecnia, v. 63(244): pp. 611-621, DOI: $10.4321 / \mathrm{s} 0004-05922014000400005$.

Plavnik, I. \& Hurwitz, S. (1988). Early feed restriction in chicks: Effects of age, duration, and sex. Poultry Science, 67(3): pp. 384-390, DOI: $10.3382 /$ ps.0670384.

Peng, M., Han, J., Li, L. \& Ma, H. (2016). Suppression of fat deposition in broiler chickens by (-)-hydroxycitric acid supplementation: A proteomics perspective. Scientific Reports, v. 6: pp. 1-11, DOI: $10.1038 /$ srep32580.

Popova, T., Ignatova, M., Petkov, E. \& Stanisic, N. (2016). Difference in fatty acid composition and related nutritional indices of meat between two lines of slow growing chickens slaughtered at different ages. Archives Animal Breeding, v. 59(3): pp. 319-327, DOI: 10.5194/aab-59-3192016.

Prabakaran, R. (2003). Good practices in planning and management of integrated commercial poultry production in South Asia (No. 159). Food \& AgricultureOrganization, Rome.

SAS (2002). Statistical Analyses System. Users Guide Statistics. SAS Institute Inc. Cary, North Carolina, USA.

Shahin, K.A. \& El Azeem, F.A. (2006). Effects of breed, sex and diet and their interactions on fat deposition and partitioning among depots of broiler chickens. Archives Animal Breeding, v. 49(2): pp. 181-193, DOI: 10.5194/aab-49-1812006.
Santoso, U., Tanaka, K., Ohtani, S. \& Cecora, J. (1993). Effects of early skip day feeding on growth performance and body composition in broilers. Asian Australasian Journal of Animal Sciences, 6(3): pp. 451-461, DOI: 10.5713/ajas.1993.451.

Santoso, U., Tanaka, K. \& Ohtani, S. (1995). Does feed-restriction refeeding program improve growth characteristics and body composition of broiler chickens? Animal Science and Technology, v. 66(1): pp. 27-35, DOI: 10.2508/chikusan.66.27.

Santoso, U. (2001). Effects of early feed restriction on growth, fat accumulation and meat composition in unsexed broiler chickens, Asian-AustralasianJournal of Animal Sciences, v. 14(11): pp. 1585-1591, DOI: 10.5713/ajas.2001.1585.

Tumova, E. \& Teimouri, A. (2010). Fat deposition in the broiler chicken: A review. Scientia Agriculturae Bohemica, v. 41(2): pp. 122-128.

Yang, X., Zhuang, J., Rao, K., Li, X. \& Zhao, R. (2010). Effect of early feed restriction on hepatic lipid metabolism and expression of lipogenic genes in broiler chickens. Research in veterinary science, v. 89(3): pp. 438-444, DOI: 10.1016/j.rvsc.2010.04.003.

Yu, M.U., Robinson, F.E., Clandinin, M.T. \& Bodnar, L. (1990). Growth and body composition of broiler chickens in response to different regimens of feed restriction. Poultry Science, v. 69 (12): pp. 2074-2081, DOI: 10.3382/ps.0692074.

Zhan, X.A., Wang, M., Ren, H., Zhao, R.Q., Li, J.X. \& Tan, X.L., (2007). Effect of earlyfeed restriction on metabolic programming and compensatory growth in broiler chickens. Poultry Science, v. 86(4): 654-660, DOI: $10.1093 / \mathrm{ps} / 86.4 .654$.

Zubair, A. K. \& Lesson, S. (1996). Changes in body composition and adipocyte cellularity of male broilers subjected to varying degrees of early-life feed restriction. Poultry Science, v. 75(6): pp. 719728 , DOI: 10.3382/ps.0750719. 